\title{
Verbond en kinderdoop in die patristiese literatuur - enkele opmerkings
}

\author{
JJ ENGELBRECHT
}

Met die term "patristiese literatuur" dink ons aan Christelike literatuur uit die eerste paar eeue, met die uitsondering van die kanonieke geskrifte. Oor die presiese omvang van hierdie literatuur heers daar geen eenstemmigheid nie (Van Unnik 1960: 401-402). Die patristiek is die wetenskap wat hom besig hou met die geskiedenis van die ou kerk tot die tyd van Johannes Damascenus in die agtste eeu. Met die "patres", dit wil sê "vaders", is aanvanklik bedoel "kerkvaders" of leraars wat deur hul leer en lewe groot invloed op die ontwikkelingsgang van die kerk uitgeoefen het. Deesdae word dié term gebruik om ook mense in te sluit wat nie aan bogenoemde beskrywing beantwoord nie en wat selfs in later tyd as ketters beskou is (Van Unnik: 1960: 402).

Sedert die sewentiende eeu word 'n groep van die oudste nie-kanonieke Christelike geskrifte met die benaming "Apostoliese Vaders" aangedui. Tradisioneel is aanvaar dat die betrokke skrywers nóu met die apostels of met die leerlinge van die apostels geassosieer was. Sommige van hierdie geskrifte het tot in die vierde of vyfde eeu ' $n$ kwasi-kanonieke gesag in sekere kerke gehad. So is byvoorbeeld die brief van Barnabas in die Codex Sinaiticus opgeneem en die twee Klemensbriewe in die Codex Alexandrinus (Shephard 1982: 174).

Ons opmerkings oor die verbond en die kinderdoop in die patristiese literatuur is hoofsaaklik beperk tot die eerste drie eeue.

\section{KINDERDOOP}

\subsection{Aanduidings dat die kinderdoop beoefen is}

In sy boek getitel Die Kindertaufe in den ersten vier Jahrhunderten, wat reeds in 1958 verskyn het (Jeremias 1958: 11-22), gee Jeremias in twaalf bladsye ' $n$ breedvoerige lys van vroeg-kerklike bronne vanaf 1 Korintiërs tot die geskrifte van Augustinus in die eerste helfte van die vyfde eeu, wat syns insiens in een of ander opsig op die debat rondom die 
kinderdoop betrekking het. Hy gee nuttige inligting oor publikasies waarin hierdie tekste in die oorspronklike taal en of in vertaalde vorm vir die navorser beskikbaar is. Jeremias het die tekste waarin die kinderdoop uitdruklik vermeld is met 'n asteriscus gemerk, en dit trek dadelik 'n mens se aandag dat die eerste asteriscus eers by 'n derdeeeuse dokument verskyn, naamlik by Tertullianus se De Baptismo. Dít skep in elk geval die indruk dat die kwessie van die kinderdoop vóór die begin van die derde eeu nie 'n probleem in die kerk was nie: Wanneer iets in die kerk problematies word, vind dit gewoonlik ook skriftelike neerslag. Daarteenoor sou dit nie verantwoord wees om uit die "swye" van die eerste- en tweede-eeuse dokumente sonder meer af te lei dat die kinderdoop dus onbekend of ongeoorloof was nie. Dit is moontlik dat ' $n$ saak kan bestaan en veronderstel word selfs al word dit nie uitdruklik vermeld nie.

Vervolgens word kortliks gelet op 'n paar tersake gegewens wat deur middel van die betrokke literatuur onder ons aandag kom. Wanneer Justinus die martelaar (ongeveer 105-165) die dooprite beskryf, sê hy onder andere dat hulle wat glo wat "ons" leer en dienooreenkomstig wil lewe, opdrag kry om God in gebede en vaste te vra om vergiffenis van hulle sondes. Hulle word na 'n plek geneem waar daar water is en daar word hulle gebad (loutron) in die Naam van dié Vader, ..., Jesus Christus en die Heilige Gees (Justinus).

Die "Didache" of "Leer van die apostels" wat waarskynlik teen die einde van die eerste of die begin van die tweede eeu in Sirië ontstaan het, gee belangrike doopvoorskrifte. Daarin word gesê dat as daar nie lewende (lopende) water beskikbaar is nie, enige ander water vir die doop gebruik kan word. As koue water nie beskikbaar is nie, is warm water geskik en as albei ontbreek, moet water drie maal oor die hoof gegiet word. ' $n$ Verdere voorskrif was dat die een wat die doop bedien en die een wat gedoop word, moet vas (Didache 7).

Justinus en die Didache verwys hoegenaamd nie na die kinderdoop nie en skep beslis die indruk dat die algemene vorm van die doop in die vroeë kerk die onderdompeling van volwassenes (of in elk geval nie van suigelinge nie) was (Vgl Oetting 1970: 29). Hiermee is nog nie gesê dat kinderdoop en besprenkelingsdoop in beginsel of praktyk verbode was nie. Dié aspekte van die doop word gewoonweg tot in daardie tyd nog nie vermeld nie.

Hippolytus (ongeveer 160-235) vertel dat wanneer die dopeling in die water afgaan, die een wat die doop bedien aan hom drie vrae stel. 
Telkens wanneer op so 'n vraag geantwoord is: "Ek glo", is die dopeling onderdompel

Jeremias (1958: $87 \mathrm{ev;} 107 \mathrm{ev)}$ beroep hom op veral die Koptiese teks van Hippolytus se kerkorde en konkludeer dat Hippolytus die kinderdoop as "onbestrede reël" veronderstel wat geen regverdiging nodig het nie. Volgens Jeremias se vertaling van die Koptiese teks moes die kinders eerste gedoop word. Almal wat self kon praat, moes praat. Die ouers of ' $n$ ander familielid moes egter praat namens die wat nie kon praat nie.

Teen die einde van die tweede of die begin van die derde eeu is daar by Tertullianus (ongeveer 160-220) moontlik ' $n$ indirekte verwysing na 'n praktyk dat die kinders van Christenouers wel gedoop is, wanneer hy adviseer dat kinders van heidenouers wat in pleegsorg (?) by Christene is, se doop uitgestel moet word, behalwe wanneer dit om 'n nooddoop gaan (Jeremias 1958: 95, 115). Sy argumente is dat dit nie wenslik is om so 'n verantwoordelikheid op die voogde te plaas nie. Hy gee toe dat die Here sê dat die kindertjies nie verhinder moet word om na Hom te kom nie, maar sê dan dat hulle moet kom wanneer hulle groot geword het. Aangesien die kinders syns insiens onskuldig is (innocens aetas), is daar geen haas dat hulle gedoop moet word nie.

Ietwat meer as 'n eeu later sou ook Gregorius van Nasianse (ongeveer 329-389), een van die drie groot Kappadosiese kerkleiers, 'n uitstel van die doop aanbeveel. Hy beveel egter slegs aan dat die doop tot die ouderdom van ongeveer drie jaar uitgestel word. Sy fundering daarvoor is bloot die wens dat die kinders minstens in staat moet wees om iets misties te kan snap, self te antwoord en 'n indruk te kan kry. Jeremias (1958: 115) maak in aansluiting hierby die opmerking dat die meeste ouers wat in die vierde eeu die doop van hulle kinders uitgestel het totdat hulle die jeugdige storm- en drangperiode oorwin het, nie deur ernstige teologiese oorwegings gemotiveer is nie, maar gelei is deur (bestimmt von) 'n magiese misverstand oor die doop.

Dít wat die uitstel van die doop betref, maar kom ons keer terug na skriftelike gegewens oor die dooppraktyk voor die derde eeu: Uit die eerste en tweede eeu self het ons geen ander skriftelike getuienis as die wat ons reeds genoem het nie. Origines (skryf ongeveer 230-250) maak egter ' $n$ belangrike stelling oor die dooppraktyk voor die derde eeu as hy vier maal beweer dat die kinderdoop (hy praat van paidia/parvuli) reeds vanaf die tyd van die apostels in die kerk gebruiklik was: Ecclesia $\mathrm{ab}$ apostolis traditionem suscepit. Hy skryf iewers tussen 233 en 251 n.C., maar sy opmerking verwys terug na 'n heelwat vroeër tydperk, 
want Eusebius sê dat Origines se familie reeds verskillende geslagte lank Christene was. Origines kon moeilik van 'n tradisie wat van die apostels oorgeneem is praat as hy nie geweet het dat minstens sy vader en waarskynlik ook sy grootvader as kinders gedoop is nie. Die oorlewering van Origines se familie voer ons dus terug tot minstens die tyd toe sy vader gedoop is, dus die middel van die tweede eeu. Waarskynlik selfs tot die tyd toe sy grootvader in die eerste helfte van die tweede eeu gedoop is (Jeremias 1958: 75-77).

Volgens Jeremias (1958: 81) dra Origines se uitsprake besondere gewig weens sy wye gesigsveld. Hierdie geleerde is uit 'n Egiptiese gesin gebore en het tot in 231 in Aleksandrië gewoon; die opmerkings wat deur Jeremias aangehaal is dateer uit sy werktyd in Sesarea in Palestina; boonop het hy op sy talryke reise Rome, Griekeland, Wes-Sirië, Kappadosië en die deel van Arabië wat aan Palestina grens, besoek. Hy kon nie so ongereserveerd van die suigelingsdoop as ecclesiae observantiae gepraat het as hy tydens sy omvangryke reise deur die kerk afwykende gebruike teengekom het nie. Origines se getuienis het dus op feitlik die hele Oostelike kerk in sy tyd betrekking (Jeremias 1958: 81).

Tertullianus se besware het skynbaar geen indruk op Cyprianus (ongeveer 200-258) gemaak nie. Laasgenoemde noem die belangrike feit dat toe daar in 'n sinode te Kartago in 251 of 253 'n poging was om te reël dat die doop volgens die voorbeeld van die besnydenis eers op die agtste dag na die geboorte bedien moet word (behalwe in noodgevalle), daar besluit is dat vanweë die erfsonde daar nie met die doop tot die agtste dag gewag behoort te word nie. Die kinders moet direk na die geboorte gedoop word (intra secundum vel tertium diem). Uit 'n ander geskrif van Cyprianus blyk ook dat dit gebruiklik was om die nagmaal aan klein kindertjies te bedien - Die vanselfsprekende veronderstelling is dat hulle gedoopte kindertjies is (Jeremias 1958: 100).

Jeremias (1959: 101) kom tot die gevolgtrekking dat 'n mens oral, behalwe in Oos-Sirië, die kinderdoop in die tweede eeu aantref as 'n ou en vaste gebruik wat na die apostels self teruggevoer word. So ver as wat enige aanduidings bestaan word die suigelingsleeftyd (Irenaeus), of meer presies, die eerste dae na die geboorte (Origenis, Cyprianus) genoem.

Die skrale inligting by die patres in die eerste twee eeue met betrekking tot die kinderdoop, word uiteenlopend geïnterpreteer: Sommige lei daarvan af dat die kinderdoop onbekend in die vroeë kerk was 
(Aland 1971: $28 \mathrm{ev);} \mathrm{ander} \mathrm{sê} \mathrm{dat} \mathrm{die} \mathrm{kinderdoop} \mathrm{vanaf} \mathrm{die} \mathrm{ontstaan} \mathrm{van}$ die NT 'n algemene praktyk was, maar dat die patres in die eerste twee eeue so min aandag daaraan skenk omdat dit geen noemenswaardige probleme in die kerk veroorsaak het nie. Vanaf die derde eeu word die praktyk wel vermeld, maar dan sonder enige aanduiding dat dit as iets nuuts beskou is (Jeremias 1958: $58,110-1$ ).

Jeremias maak daar 'n sterk punt van dat as die kinderdoop nie reeds vanaf 'n baie vroeë stadium ja, van die Nuwe-Testamentiese tyd af, 'n bekende praktyk was nie, dit ondenkbaar is dat die kinderdoop vanaf die derde eeu so spanningloos vermeld kan word in die Christelike lektuur van daardie tyd en dat daar geen spoor is van spesiale veranderings in die doopgebruike en voorskrifte om voorsiening te maak vir wat dan 'n nuwe gebruik sou wees, naamlik om die kindertjies van gelowiges te doop nie (Jeremias 1958: 58, 110-1).

Hy noem ook nog ander gegewens, byvoorbeeld die brief van Aristides en Polycarpus se stelling dat hy al 86 jaar die slaaf van die Here is, maar die inligting wat ons reeds gemeld het is voldoende vir ons doel.

\subsection{Gevolgtrekking in verband met die eerste twee eeue}

Vir diegene wat oortuig is dat die kinderdoop reeds in die Nuwe Testament veronderstel word en destyds reeds beoefen is, en wat oortuig is dat die oikostekste in die Nuwe Testament die kinderdoop steun, sal dit redelik maklik wees om te aanvaar dat die kinderdoop van die tyd van die apostels af die algemene gebruik in die kerk was. Vir diegene egter wat nie so seker van die Nuwe-Testamentiese situasie is nie, sal dit makliker wees om die beskikbare en helaas skrale gegewens so te interpreteer dat die kerk eers in die derde eeu danksy teologiese refleksie (wat goed of sleg kan wees) tot die praktyk van die kinderdoop oorgegaan het.

Sedert die eerste derde van die vierde eeu is daar aanduidings van wat Jeremias (1958: 102-114) 'n krisis noem: Nie alleen heidene wat tot bekering kom, stel hulle doop so lank as moontlik uit nie, maar ook Christenouers stel die doop van hulle kinders so lank as moontlik uit, omdat skynbaar geglo is dat sondes wat ná die doop gedoen word, veel moeiliker vergewe word as die waaraan hulle voor die doop skuldig is. Dit is opvallend dat die "grootdoop" nie gepropageer word met die argument dat die Bybel dit eis of dat 'n suigeling nie kan glo nie. Totaal ander sake speel hier 'n rol, naamlik 'n misverstand oor die betekenis van die doop. 
Augustinus, die sterk kerklike leiersfiguur in die eerste helfte van die vyfde eeu, was grootliks daarvoor verantwoordelik dat die praktyk om die doop so lank as moonlik uit te stel, begin kwyn het. Van toe af kom daar sinodale besluite wat die kinderdoop vermeld en in 418 spreek die Sinode van Kartago die vervloeking uit teen elkeen wat parvulos recentes ab uteris matrum baptizandos negat (Jeremias 1958: 114). Hy fundeer die kinderdoop teologies op die originale peccatum (Bright 1903: 169-170; Nagel 1980: 166-169).

\section{VERBOND EN KINDERDOOP}

Skrywer hiervan kon geen eksplisiete of implisiete verwysing na die verbond of 'n verband tussen verbond en kinderdoop in die literatuur van die eerste vyf eeue opspoor nie.

\section{Literatuurlys}

ALAND, K 1971. Taufe und Kindertaufe. Gütersloh: Mohn.

BRIGHT, W 1903. The age of the fathers. Being chapter in the history of the church during the fourth and fifth centuries II. Reprinted, New York: AMS.

DIDACHE. 2de eeu. Vertaling by Oetting; teks en vertaling by Lightfoot.

HYPPOLYTUS. Apostoliese tradisie. Engelse vertaling uit Latynse vertaling.

JEREMIAS, J 1958. Die Kindertaufe in den ersten vier Jahrhunderten. Göttingen: Vandenhoeck \& Ruprecht.

JUSTINUS. Apologie.

LIGHTFOOT, JB 1926. The apostolic fathers. Revised texts with short introductions and English translations. Edited and completed by JR Harmer. Reprinted. London: MacMillan.

NAGEL, E 1980. Kindertaufe und Taufaufschub. Die Praxos vom 3-5. Jahrhundert in Nordafrika und ihre theologische Einordnung bei Tertullian, Cyprian und Augustinus. Frankfurt aM: Lang. (Europäische Hochschulschriften. Reihe XXIII Theologie).

OETTING, W 1970. The church of the catacombs. An introduction to the surging life of the early church from the apostles to A.D. 250. Based on firsthand accounts. 2nd printing, slightly revised. St. Louis, Missouri: Concordia.

SHEPHERD, MH 1982. Apostolic fathers, in Buttrick, GA (ed). The interpreter's dictionary of the Bible. 13th printing. Nashville: Abington, 174.

TERTULLIANUS, De Baptismo. (Vertaling by Oetting).

VAN UNNIK, WC 1960. Patristiek, in Grosheide, FW \& GP van Itterzon (red). Christelijke Encyclopedie $V$. 2de geheel herziene druk. Kampen: Kok, 402. 